\title{
White-Collar Migrants in Coastal Chinese Cities
}

Entrepreneurs of Their Professional Careers

Gilles Guiheux et Pierre-Paul Zalio

\section{OpenEdition \\ Journals}

Édition électronique

URL : http://journals.openedition.org/chinaperspectives/5339

DOI : 10.4000/chinaperspectives.5339

ISSN : 1996-4617

Éditeur

Centre d'étude français sur la Chine contemporaine

Édition imprimée

Date de publication : 15 décembre 2010

ISSN : 2070-3449

\section{Référence électronique}

Gilles Guiheux et Pierre-Paul Zalio, «White-Collar Migrants in Coastal Chinese Cities », China

Perspectives [En ligne], 2010/4 | 2010, mis en ligne le 01 décembre 2013, consulté le 28 octobre 2019

URL : http://journals.openedition.org/chinaperspectives/5339; DOI : 10.4000/chinaperspectives.5339 


\author{
Entrepreneurs of Their Professional Careers
}

\author{
GILLES GUIHEUX AND PIERRE-PAUL ZALIO
}

$\eta$ he tremendous speed of urbanisation in China over the last 20 years has occurred simultaneously with a structural change in urban labour markets. In most cities, manufacturing has declined while service industries have rapidly developed. In the case of Shanghai, the service industry already accounts for more than half the city's total GDP. Today, the city government aims at building future prosperity on finance, trade, and shipping. ${ }^{(1)}$ The service sector will be at the core of Shanghai's industrial structure, making the Chinese metropolis a truly global city. ${ }^{(2)}$

Migrants coming to the metropolis are not only farmers from rural areas but also urban youth coming from second- or thirdtier cities. This study deals with moderately skilled young service workers born and educated in provinces around Shanghai who come to the most cosmopolitan and prosperous Chinese metropolis in search of a better future. Employed in service industries, they are different from the unskilled migrants working on construction sites and in other labour-intensive industries, though they likewise take rather low-paid jobs that locals look down on. They are also different from the highly skilled young Chinese (the haigui) who come back from abroad after graduating from a foreign university and working abroad, especially in the IT sector, even though they share their belief that Shanghai is the best place to be at present, where they can make their dreams come true, and where careers offer the best opportunities for success.

Some authors have argued that these mobile individuals are better prepared to take advantage of the changing structure of the urban economy. It has especially been the case that rural migrants willing to work hard eventually start their own businesses in the informal economy, as opposed to the xiagang, whose dependence on their danwei for their wellbeing, accommodation, etc., made them ill-equipped to adapt to the new environment. ${ }^{(3)}$ This perspective is in line with a classical result of the economic sociology of migration: because migrants are willing to adjust to drastic changes in living and working conditions - which implies not only practical changes but also changes in values, cultures, or meanings - they are better equipped to seize opportunities in a rapidly changing urban economy characterised by uncertainty and risks. ${ }^{(4)}$

This paper intends to contribute to the analysis of the diversity of the changing labour regimes in contemporary urban China. A decade ago, authors studied blue-collar workers and the new factory regimes replacing the declining danwei system. ${ }^{(5)}$ More recent works deal with white-collar workers: sales clerks in department stores, hotel employees, professionals such as engineers and lawyers, or semi-independent workers such as insurance sales agents. ${ }^{(6)}$ Majors themes of these studies are the decline of state authority in the workplace, the alienation of workers, the gender identities or the flexible meanings and experiences of "localism," "community," and "class." ${ }^{(7)}$ Lisa Hoffman ${ }^{(8)}$ and Xia Zhang, ${ }^{(9)}$

1. Zhang Zhenghua, "Shanghai to base growth on service industry," China Daily, 25 January 2008 , p. 4

2. On the changing structure of employment, see Peter Evans and Sarah Staveteig, "The Changing Structure of Employment in Contemporary China," in Deborah Davis and Feng Wang (eds.), Creating Wealth and Poverty in Post-Socialist China, Stanford, CA, Stanford University Press, 2009, pp. 69-84. The authors argue that most jobs will be created in the service industry in the long run, leading to growing income disparity.

3. See Dorothy J. Solinger, "Labour Market Reform and the Plight of the Laid-off Proletariat," The China Quarterly, 170, June 2002, pp. 304-326. According to Solinger, "Since the urban ex-workers have spent their adult working lives at factory machines in the cities, most have not had an opportunity to acquire either the brawn or the specialized service skills that are the mark of the farmer or the rural craftsperson. By contrast, the capabilities that peasants developed in their past pursuits enable them when in town to outcompete urbanites in a number of critical trades (but not in all occupations)" (p. 314).

4. Alejandro Portes (ed.), The Economic Sociology of Immigration, New York, Russel Sage Foundation, 1995.

5. See for instance Ching Kwan Lee, "From Organized Dependence to Disorganized Despotism: Changing Labour Regimes in Chinese Factories," The China Quarterly, 157 March 1999, pp. 44-71; Pun Ngai, "Becoming Dagongmei (Working Girls): The Politics of Identity and Difference in Reform China," The China Journal, 42, July 1999, pp. 1-18.

6. Ching Kwan Lee (ed.), Working in China: Ethnographies of labor and workplace transformation, New York, Routledge, 2007; Eileen M. Otis, "Beyond the Industrial Paradigm: Marked-Embedded Labor and the Gender Organization of Global Service Work in China," American Sociologial Review, 73, February 2008, pp. 15-36.

7. See Ching Kwan Lee, "Mapping the terrain of labor ethnography," in Ching Kwan Lee (ed.), 2007, pp. 15-37.

8. Lisa Hoffman, "Autonomous Choices and Patriotic Professionalism: On Governmentality in Late-Socialist China," Economy and Society, vol. 35, no. 4, 2006, pp. 550-570.

9. Xia Zhang, "Ziyou (Freedom), Occupational Choice and Labor: Bangbang in Chongqing, PRC," International Labor and Working Class History, 73, 2008, pp. 65-84. 
building on the works of Michel Foucault on governmentality, and Aihwa Ong on neo-liberalism, have underlined how urban Chinese labourers have been transformed into self-reliant subjects, vulnerable to a high degree of exploitation, and reveal how job choice is in fact a mechanism of governing and subjectivation. ${ }^{(10)}$

Our collection of life stories of young white-collar migrants shows that working in Shanghai induces a radical change from previous domestic and professional environments; once in the metropolis, migrant workers experience a completely new set of situations and values. Since Robert Park, it has been repeatedly underlined by the sociological literature on modernity and urbanisation that settling in a large city leads to individualisation. ${ }^{\text {(II) }}$ To adjust to the requirements of the urban labour market, workers become highly flexible: they work long hours and are willing to frequently change jobs. But they are not indefinitely passive and docile, as if there were uniformly atomised individuals facing the market. The most flexible forms of organisation of labour call for some institutional framework and leave room for individual reflexivity, actor strategies, and collective actions. Under certain conditions related to labour laws, the organisation of labour, the cycles of urban development and speculation, and the manner in which urban residents cope with them - conditions that only biographical interviews can reveal - individual workers are able to appropriate some resources, individually or collectively, and to accumulate assets and capabilities so as to maintain control of their careers. ${ }^{(12)}$ In some other circumstances, a switchback career may enable workers to recount their story to the sociologist. ${ }^{(13)}$ Analysing the careers of petty white collars workers in a Chinese city through that perspective leads us to combine economic and urban sociology. In so doing, we reject a perspective that would relate success to the personal psychological qualities of individuals and instead relate it to the forms of organisation of labour, which are in turn closely connected to the urbanisation process. Shanghai as a city is a sociological framework for studying labour - its flexibility, its instability, the hybridation of status between employment and self-employment. Conversely, individual careers allow a micro-sociological perspective on urban dynamics. While studying workers in new urban service professions, this paper aims at a better understanding of what it means to be an entrepreneur of oneself in today's China.

The study is based on fieldwork carried in Shanghai in June 2007 and January 2008. ${ }^{(14)}$ Seventeen real estate brokers were interviewed. ${ }^{(15)}$ Some were employees of international or domestic companies, and some were working as their own bosses. Some were in their early twenties with only a few months' or a few years' experience; others were in their late thirties with at most ten years' experience. They were mostly men (only two women were interviewed). They were interviewed at their office locations, for the most part in different areas of the city centre (Huangpu and Jing'an districts), where they mostly dealt with middle or upper-range properties. All of them were operating on the secondary market, renting and selling properties. ${ }^{(16)}$

In the first part of the study, we introduce the population of real estate brokers as a group of individuals who are prepared by their migratory path to take the dirtiest service industry jobs on the urban flexible labour market. Working as a real estate agent can be a first and temporary step into the Shanghai labour market; due to poor working conditions, the turnover is high. In the second part, we reveal that the careers can be described as boundaryless, as individuals move back and forth from employment to self-employment. ${ }^{(17)}$ For an individual, the ability to transform turning points in one's career into an opportunity is in fact strongly dependant, as shown in Part Three, on working conditions: employers may allow or even favour teamwork that offsets the instability of switchback individual careers, or individuals can appropriate skills or assets - specific knowledge of singular goods such as old houses or net-

10. See also Gilles Guiheux, "The Promotion of a New Calculating Chinese Subject: The Case of Laid-off Workers Turning into Entrepreneurs," Journal of Contemporary China, vol. 1650, February 2007, pp. 149-171.

11. Robert Park, "The Urban Community as a Spatial Pattern and a Moral Order," in E. W. Burgess (ed.), The Urban Community, Chicago, University of Chicago Press, 1926, pp. 318.

12. In the case of mid-twentieth-century urban America and talking about the link between a form of fieldwork (life-history interviews) and the kind of control people have in telling their own life like as a career, Audrey Collin underlines: "The rhetorical use of the discourse of career (...) offered individuals an epic narrative of the heroic life, that, despite the personal costs involved, provided the meanings and motivation to engage their continuing effort, skills and commitment. At the same time, and informed by career theory and articulated in the practices of vocational guidance, it also allowed individuals to make good what was otherwise missing in their work lives. For those with an elite career, this rhetoric restored the wholeness and authenticity lost in the epic struggle; for those without, it allowed them to construct a sense of agency, continuity, and potential for development." Audrey Collin, "Epic and novel: The rhetoric of career," in Audrey Collin and Richard A. Young (ed.), The Future of Career, Cambridge (UK), Cambridge University Press, 2000, p. 172.

13. Richard Senett, The Corrosion of Character: The Personal Consequences of Work in the New Capitalism, New York-London, Norton, 1998.

14. Fieldwork was made possible by a CEFC research grant.

15. In the rest of the paper, informants' names have been changed

16. The profession started when the first office and residential buildings were built for sale on the emerging the real estate market. At that time, real estate brokers were mostly selling brand new properties on the primary market.

17. Michael B. Arthur and Denise M. Rousseau (eds.), The Boundaryless Career: A New Employment Principle for a New Organizational Era, New York, Oxford University Press, 1996. 


\section{Special Feature \\ ת \\ worked contacts of clients or co-workers - and a significant part of the transaction's profits. Most of the time, however, powerless individuals may be forced to look for another hopefully better position in another sector. Beyond a de- scriptive typology of Shanghainese real estate brokers, the analysis reveals the conditions allowing the urban experi- ence to become an opportunity for ascending mobility and entrepreneurship careers. \\ Young service workers attracted by the metropolis}

The commodification of residential and commercial urban real estate in the 1990s has gradually led to the emergence of new intermediary (zhongjie) workers helping property owners and clients finalise deals on the market. Real estate brokers (fangdichan jingjiren) can be defined as intermediaries between property owners and buyers or tenants. They focus on expanding the pool of properties they are in charge of, on looking for clients, and on helping them not only with the real estate deal itself, but also with all the related processes with banks and concerned administrations. The first national regulations for the profession were the Measures for the Administration of Brokers (Jing̈̈rren guanli banfa) issued by the State Administration for Industry and Commerce on 26 October 1995 to "normalise the work of real estate agents, protect the legal rights of persons involved in the work of real estate agents, and stimulate the healthy development of the trade." The document has been revised since then, and many other regulations have been issued at the national and local levels. In Shanghai itself, tens of thousands of individuals, some licensed, others unlicensed, are involved in the trade. Precise figures are not publicly available from the Shanghai Association of Real Estate Brokers; moreover, figures are highly dependent on business cycles, since individuals easily enter and leave the trade. For instance, in the course of a few months in 2008, the total number of agents was said to have been reduced by more than half, from 100,000 to 45,000 . $^{(18)}$

\section{Coming to shanghai, moving to opportu- nities}

Most of the brokers interviewed were in their twenties or thirties and came to Shanghai from nearby provinces (Jiangsu, Hubei, Hunan, Zhejiang). ${ }^{(19)}$ They came from different social backgrounds: most of their parents were workers or farmers, while the parents of a few of them had benefited from a
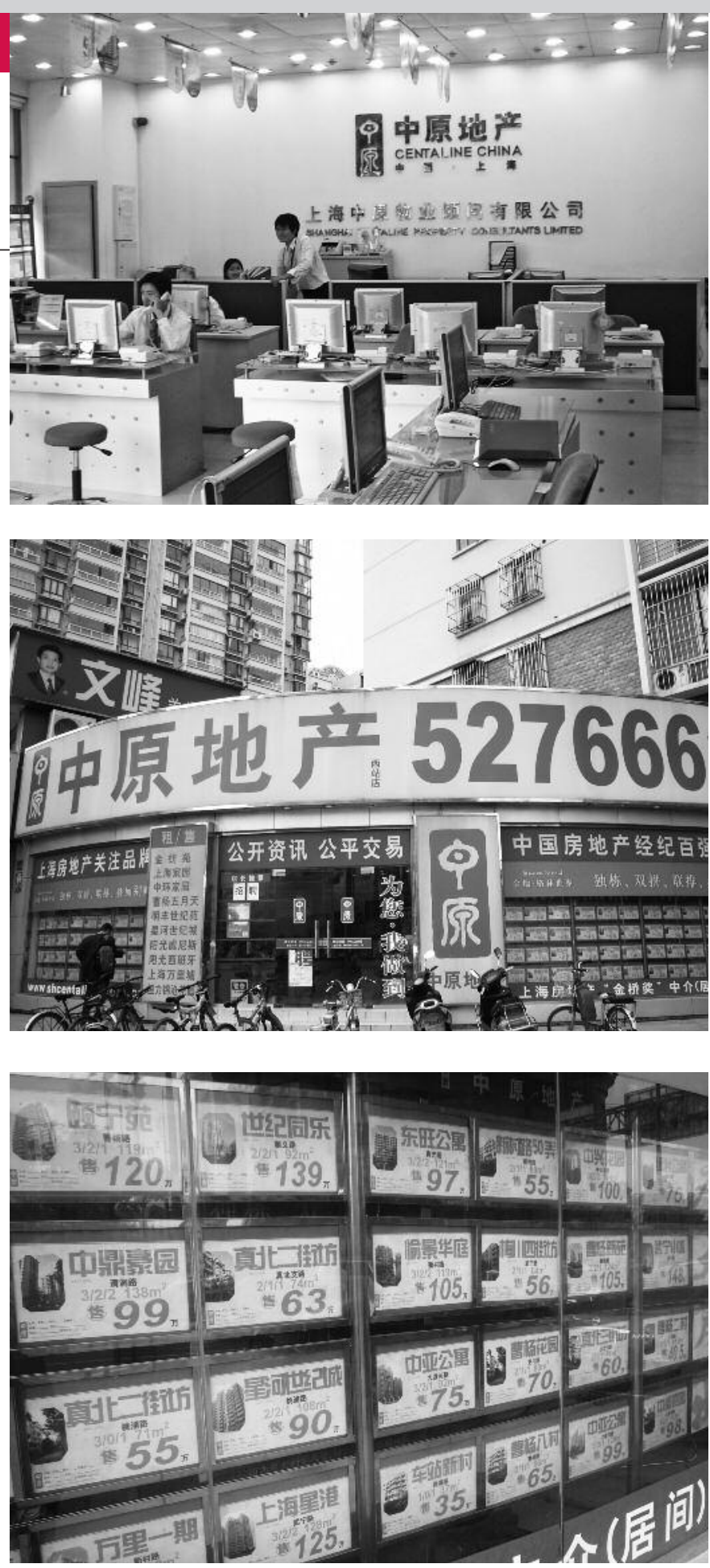

college education. In terms of education level, all had graduated from high school. Some of them had started to work straight after high school, while others had studied for a vocational degree (dazhuan) and graduated, for instance, in the textile industry or maritime transport. Some even possessed a bachelor's degree (Xie had a B.A. in communications and

18. "Shanghai shiwan fangdichan jingjiren jianyuan guoban," Diyi caijingribao, 10 0ctober 2008, http://cd.360fdc.com/ news/particular-303718.html).

19. A recent Shanghai Daily article states that "among the city's realtors, who fluctuate in number between an estimated 70,000 and 100,000 , the majority are non-Shanghai natives with high-school degrees or equivalent or even lower educational backgrounds." "Crackdown on illegal property agencies will start next month," Shanghai Daily, 22 February 2010, http://www.shanghaidaily.com/sp/article/2010/201002/20100222/article 429145.htm. 
media studies). One of them justified in the following terms why these two or three years in college were useful to their job: "We have a good appearance (yibiao)" (Fan). Mastering social skills such as how to behave in various social contexts is a key to success in an industry where workers deal with people coming from various social backgrounds.

Before coming to Shanghai, these brokers had a variety of previous work experience. Some had worked for government administrations, some for state-owned companies, others for private firms. After graduating in 1995, Sun was allocated (fenper) a job in a state-owned maritime company, where he worked for two years. Asked what made them leave their previous occupations, they gave several reasons: either they did not enjoy their work environment, or they lacked incentives to continue their job, or they felt they could not achieve a career. Xie's first job was in his hometown, a small city in Jiangsu Province: "I was happy and also relaxed (qingsong), but opportunities were scarce. The salary was ordinary. You cannot compare it with Shanghai." Sun, who was working in a state-owned company, realised he was not really interested in the work and decided to quit. Han graduated in accounting from a university in Changsha (Hunan), his native town, and was then assigned to a position in Wuhan (Hubei) in charge of sales; one of the reasons he mentioned for giving up his job was that it was not related at all to his academic qualifications. Xiao, after graduating in 1997, was appointed (fenpei) to an administration in his hometown where he remained for five years. He then realised he was not very happy with this job and would enjoy a job with more contact with the outside world. He also considered his efficiency pretty low (xiaolü tai $\left.d_{i}\right)$ :

In the six months before leaving [my hometown], I was continuously reflecting on what I was really after (wo yizhi zai xunqiu ziji yao gan shenme). If I studied management, it was because I thought I would enter a company that dealt with the market (xiang jinru shichanghua de gongsi gongzuo). The efficiency level of government jobs is low. The space for personal development is limited (geren de fazhan kongjian shoudao xianzhi).

These three informants relate their decisions to personal reflection on how their jobs fit their personalities. One refers to the mismatch between one's job and one's learned skills; another mentions his personal interests and the third uses rhetoric that is embedded in the new labour regime: he refers to the need for efficiency on the one hand and for per- sonal development on the other. Leaving a previous job is the result of an individual's reflection on his or her own capacities and on the possibility of taking personal advantage of the economic environment. Of course, these are constructed narratives, and informants, in their discourse, retrospectively rationalise their experience to make it compatible with the urban job market that constrains their choices. But the urban labour market is also a framework for individual reflexivity. ${ }^{(20)}$

To the question of how they chose to work in real estate rather than in another industry, our informants provided several answers. Most of them didn't have much knowledge of the industry before starting and chose it mostly because it was easy to make money.

When I started working, I could not really say I was interested in the industry. I had never been in touch with the industry before. What I knew was that I could earn enough money. (Xie)

- Why did you come to Shanghai?

- To make money. I had been everywhere: Beijing, Qingdao. I had travelled. At one point, I was working in Beijing. It was also in real estate. But Beijing's real estate market is not as developed as Shanghai's. That's why I came to Shanghai (...) I worked for a month in Beijing. I had friends there who were working in real estate.

- Why did you decide to leave Beijing?

- Because Beijing's real estate market is not so good. Shanghai's market is very good. That's why I came to Shanghai. (Yang)

Others had a rather shallow knowledge of the industry:

Before leaving my job with the government, I needed to choose an industry. One option was information technologies; the other option was real estate. At that time, these were the two industries where it was easier to make money. I gathered a lot of information. I compared. And then I concluded that working in the real estate industry suited my own interests better (geng fuhe wo de xingqu). As a person, I have hopes

20. Various conceptions of actions are deposited like sediments in the urban space. Through their experience of the urban labour market, actors find holds for elaborating on their activities. See P.-P. Zalio, "L'acteur économique et le projet urbain: De l'histoire des représentations à l'horizon d'action des entrepreneurs," L'Année sociologique, 2008 vol. 58, no. 1, pp. 95-117. 
(...). I enjoy talking with other people. And at that time, real estate was a booming sector and I was tempted to be part of it (...). What made me decide to choose real estate was a lecture by a professor (...). This professor told us that real estate was going to become the first pillar industry of the Shanghai economy. (Xiao)

Many of them did not have a clear idea of the exact nature of the industry. But they were optimistic about its future. In fact, rather than choosing a profession (real estate), they chose a city: Shanghai. Their main motivation for leaving their hometown or their first occupation in some other Chinese city was the attracting power of the metropolis. This is another feature that confirms that they should be considered migrants: displacement or mobility is more important to them than the change of occupation.

Many of them seem to have had very little knowledge of Shanghai and came to have a look at it in the first place, not even considering from the outset that they might settle there and look for a job. The lights of the Shanghai metropolis attracted them well before they started looking for a job. Han arrived in Shanghai without any previous knowledge of the city:

I am the one who decided to quit and to come to Shanghai. I knew nothing of Shanghai. I came for the first time in August 1998. Why come to Shanghai? We Hunan people would rather go to Guangzhou, Shenzhen - these cities are closer. At that time, in the 1990s, logically, Hunan people were rather numerous in Guangdong or Shenzhen. At that time I thought it would not do for me. I thought Shanghai suited me better. Beijing is a big city, but Beijing is the political centre. I thought it would not do for me. That's how I came to Shanghai.

Yang first came to Shanghai to have fun; only afterward did he look for work: "I rented my own place (...) The first time I came to Shanghai, it was for fun (lai wan). I was not thinking of looking for a job." On his personal webpage, another broker tells the same kind of story:

I am originally from Fujian. I love to travel. My dream was to come to Shanghai. In this bustling city, I want to succeed in my career. That is why I chose to sell real estate, a job that requires passion and perseverance. ${ }^{(21)}$
Here is the story of another of our informants:

Three of my university classmates came to work in Shanghai. They told me you could make money in this industry. In fact, at the time I thought of going to Shanghai just for a glance, as a tourist (...) to have a look. And I stayed. I realised there were many opportunities in Shanghai. The city is large. Money is everywhere (biandi dou shi huangjin). It all depends on your ability to seize opportunities. So I thought I would look for a job in Shanghai. Why go into real estate? In fact, I did not know much about the industry. $\left(X_{i e}\right)$

These young moderately-skilled service workers are highly mobile. Some of them travelled to several other cities - and worked there - before settling in Shanghai. Some stayed in Beijing, for instance. But they found that Shanghai is the best place to make money, and so after gaining an initial impression of the city, they decided to remain there. When it comes to finding work, real estate is an option because the market is developing fast and job opportunities are numerous. They are all the more numerous since the locals (Shanghainese) look down on service jobs: "This profession only started to develop after 1993. In 1996, there were still very few [local] university graduates who chose that occupation, because the profession had no reputation (mei you zhimingdu)" (Fan). Real estate is a service profession that Shanghainese consider "dirty work," (22) probably like many other service jobs, as stated by Cheris Chan: "Sales jobs, especially personal sales, are traditionally not considered a respectable occupation in Chinese society. The inherently low social status of sales persons and the commission-based income system further burden the morale and productivity of sales agents in China." (23)

\section{Willing to work hard, a search for autonomy}

Brokers are the first to acknowledge the fact that they are the petty workers of a new service activity related to urbanisation and privatisation of the housing stock. They are inter-

21. http://esf.sh.soufun.com/a/zhangjun666 (12 June 2008). Soufun is the largest Chinese real estate website. Properties are advertised by brokers who can pay a monthly fee for a personal public webpage.

22. Everett Hughes, Men and their work, Glencoe (II.), Free Press, 1958.

23. Chan Cheris Shun-ching, "Honing the desired attitude: Ideological work on insurance sales agents," in Ching Kwan Lee (ed.), Working in China, London, Routledge, 2007, p. 236. 
mediaries between owners and buyers or tenants. They have to look for properties, meet landlords and clients, prepare negotiations with banks for loans, and facilitate the whole administrative process with the relevant authorities - notably the procedures for recording transactions. They are the proletariat or working class of the real estate business. During our interviews, those who started in the profession at the beginning of the commodification process narrated how they had to knock on doors in buildings, one after another, one floor after another, all day long, looking for customers. From morning to evening, work was tough $(\mathrm{ku})$.

Knowing Shanghai is not important. What is important is the ability to work hard and endure difficult working conditions:

What matters in this industry is the ability to work hard because it is a difficult occupation. Even when the weather is very hot, you have to spend the day outside. I graduated in July. During that season, weather is especially hot. We started working at 8 a.m. and we finished at $9 \mathrm{pm}$ (...). At that time [1993], we were looking for clients all over the city, in all parts of the city. You have to be brave and you need to know how to talk. Every day we knocked on more than one hundred doors, sometimes several hundred doors. (Fan)

Many men and women working as real estate brokers in Shanghai came from nearby provinces to seize some of the opportunities offered by the metropolis, believing they could be part of the Shanghai dream, the new Chinese Eldorado. Mobility, for skilled migrants, was also an attempt to escape their original social conditions. They were attracted by the city, not by the profession - though they might have learned early on that among white-collar jobs, it was a possible option for outsiders (waidiren). They had enough skills to work in an industry requiring social abilities. They were also filling a gap on the market, since locals were not willing to take on this tough and repetitive work.

These testimonies illustrate the process of making mobile subjects, or how institutional reforms have turned individuals into free labour, disembedded from the previous work units. ${ }^{(24)}$ Carefully designed policies have constructed autonomous subjects free to move from one city, from one industry, from one job to another. The growing autonomy of social actors does not mean a retreat of the state, but a change of governing techniques. As Lisa Hoffman puts it, "Freedom is not indicative of the absence of power or gov- ernance, but is a technique of governing where the regulation and management of subjects happens "through freedom." (25) Chinese urban labour markets need these unattached subjects who have internalised the necessity to be mobile and refer to it in their narratives as a choice: they are willing to move from one place to another for self-achievement; mobility is justified in terms of personal growth and achievement. Of course, not all of them succeed - far from it - but at least a few of them are able to build a career in the profession. In so doing, they become entrepreneurs of their professional careers.

\section{A hybrid status: Between salary work and self-employment}

Real estate broking is not ordinary salary work. To understand the mobility of the brokers, one needs in fact to relate it to a major characteristic of the profession: halfway between salary work and self-employment. This is first of all due to the mode of payment - a feature that is not unique to the Chinese case: real estate brokers, in China as elsewhere, generate part of their income by themselves, since only a small share of their income is a fixed amount provided as a salary by the company employing them, the rest being commissions negotiated between the client and the broker according to prescribed standards and shared between the company and the employee. ${ }^{(26)}$ The youngest and less experienced of our informants would make only a little bit more than 1,000 yuan a month, but some others could occasionally earn more than 10,000 yuan. The more deals they conclude, the higher their income.

\section{Independence within the company}

In a sense, therefore, brokers have the ability to increase their income by their own determination and hard work, which helps explain why they are prepared to work long hours, starting at 9 a.m. and leaving the office 12 hours later,

24. See Xiang Biao, "The Making of Mobile Subjects: How Migration and Institutional Reform Intersect in Northeast China," Development, 2007, vol. 50, no. 4, pp. 69-74.

25. Lisa Hoffman, op. cit., 2006, p. 553.

26. According to Article 14 of the Provisions of Shanghai Municipality on the Administration of Real Estate Agents (Shanghaishi fangdichan jingjiren guanli guiding), the service fee for broking activities in real estate may be decided through discussions between the real estate agent and the client according to the following standards: $3 \%$ or less of the concluding price for intermediate introduction, agency for buying and selling houses; $70 \%$ or less of the monthly rental for intermediate introduction, agency for leasing houses (http://www.sh.gov.cn/shanghai/node2314/node3124/node3177/node3180/userobject6ai781.html). 
six days a week. This relative independence within a company is also due to the fact that the relationships that brokers have with their clients can be so close that when they quit their company, they may be able to take their own "former clients" (laokehu) with them:

Some clients can become really close to some agents, and if the latter leave to work for another firm, their clients will follow them. (Xiao)

The clients are my own. When I leave a company, the clients follow me. This is because I have personal relationships with my clients. If you have good relations with your clients, then when you leave an employer, you take them with you. (Fan)

Some brokers actually change employers often - a feature that makes them even more independent of their employers. In less than two years (from March 2006 to January 2008), $\mathrm{Xie}$, for instance, worked for three different companies in succession. Mobility can also be observed within the same company, and another kind of opportunity offered by the industry is the possibility to quickly move upward within the company. In the case of Yang, within only one year, she worked at four different levels of responsibility: she started at the lowest level as wuye guwen, which can be translated as service industry consultant, then was promoted to gaoji wuye guwen, or senior service industry consultant, before being appointed a gaoji yingye zhuren or senior sales director, and finally, when we met her, a jingli or manager. This is one of the reasons people remain in the industry: because it gives some of them the possibility to be rapidly promoted, which means not only earning more money but also changing professional practices (in an industry where work procedures are highly repetitive).

\section{Boundaryless careers}

Another feature of the profession is the frequent change from employee status to self-employed status (or being one's own boss), and the other way round. All those we interviewed started working as salary men or women. Later on, some started their own companies. For instance, Sun first worked as an employee from 1997 to 2001 and then decided to set up his own company and become his own boss. The interesting characteristic of the profession is not so much that individuals can be either employed or self-employed, but that they frequently pass from one status to the other, in both di-

\section{The career of Han}

1998 Arrives in Shanghai. Starts working for company A.

2000 Company A goes bankrupt. He sets up his own company B with two partners - one Shanghainese, one Singaporean - introduced through common friends. The firm employs up to 15 employees.

2002 The three associates disagree and split. He sets up his own individual company $\mathrm{C}$ with only 50,000 yuan. He has up to seven employees.

2003 Eleven months after the opening of his company, the building where his shop is located is torn down and he is evicted. He joins a large company $\mathrm{D}$ as an employee.

2004 Together with a group of ten colleagues, he joins another firm E. They all follow a team leader. The new company wanted to recruit the whole team, not individuals.

2004 Five months later, he leaves company $\mathrm{E}$ because he doesn't get along well with his colleagues. He then works as an independent broker (duli jinggjiren). "When deals are coming to me, I get involved. I am then an independent broker (...). My former clients contact me. I am not taking the initiative (...) I work from home. I have my own individual licence and I can work by myself."

2005 He works as an employee again. Several of his friends already work for that firm F, and it is through them that he is introduced.

2006 Firm F, originally based in Shenzhen, leaves the Shanghai market and shuts down its activities there. He is back to individual business.

2007 May. Enters the present firm G as an employee.

rections. For instance, Fan started working as an employee in 1997, set up his own company in 1998, and then went back to salary work in 2000. In the case of Han, within a period of ten years (from 1998 to January 2008), he changed four times from the status of self-employed (either as an independent broker or as an associate in a partnership) to work for four different companies as an employee (see below).

These continuous changes are justified in the following terms:

I was too tired (tailei) [as a boss]. It was not as good as working as an employee (...). At the time, it was like right now. It [the market] was difficult. You 
earned as much money as an employee as your own boss. (Fan)

When the market is good, I would like to be my own boss to make more money. I have studied business, so I would like to set up my own company and see it grow. But the market is going through adjustments during which it is difficult for an independent firm to succeed. That's why I decided to be a salaryman in a large company. As such, there are fewer risks. (Xiao)

So it is an economic rationale that leads to the decision to set up one's own firm: making more money when the market is booming, taking a more secure job (and income) when the market is down. But it is also a social rationale, since becoming independent often means setting up a partnership with associates - which means there is a need not only for an economic but also for a social opportunity. One of the basic reasons why people easily change status from employed to self-employed is of course the low cost of entry into the industry: with only a few thousand yuan, anyone can establish him or herself as an individual real estate broker or set up a real estate company.

The regulations on the industry stipulate that in order to establish a legal real estate broking company, an applicant must gather the following assets: five persons or more who have received the Qualification Certificate for Shanghai real estate agent, capital of 100,000 yuan or more, and a fixed place of business. To become a private real estate agent, the applicant must have the Qualification Certificate, possess capital of 20,000 yuan or more, have a fixed place for broking activities, and have no criminal record in the three years prior to his or her application. ${ }^{(27)}$ But in Shanghai as elsewhere, the main asset of a broker is his pool of properties - or clients - and the only initial investment is a phone line; unless you want to create or expand your pool of clients, there is no need to rent a formal office (such as a street-front shop with a window to display the properties you're handling) or formally register your company. A broker can very well work as an intermediary from home with his or her mobile phone, as a full- or often parttime job (as secondary income). This explains why it is so difficult to evaluate how many individuals are involved in the industry, since many are part-time or illegally involved the only obstacle to an illegal practice is the inability to register transactions with the relevant authorities, but the problem is then easily overcome by renting someone else's licence. ${ }^{(28)}$
In fact, real estate is one of several industries where the boundary between employment and self-employment is increasingly blurred. At a time when there is an increasing number of short-term working contracts, the new labour regimes of part of the urban job market in China - as in many other countries - is characterised by a fading distinction between salaried work and self-employment, or between employment and unemployment. This service industry profession, new to urban China, is one more example in which careers are boundaryless and their status hybrid, ${ }^{(29)}$ the same individual being successively (or possibly even simultaneously) employed by a company and self-employed.

In fact, what these narratives reveal is less dominated agents than individuals who try to develop strategies to improve their status. If brokers are like mercenaries who offer themselves to the highest bidders, occasionally the bidders may include themselves. Brokers can learn skills - knowledge of a residential area, the control of a pool of properties or clients through their different positions and employers, and carry these skills from one employer to another. Employed or selfemployed, their activity can be considered entrepreneurial. ${ }^{(30)}$

\section{Networking, socialising, appropriating skills or assets: ways to entrepreneurial careers}

Among the key resources on which brokers build their careers are social networks. It is because they master a network of customers that they are recruited by a competitor company - which through them buys a clientele. It is also through the social networks of possible partners that they gather the necessary assets to set up an independent company. Therefore, what our interviews reveal is not atomised individuals facing the market and large firms, exploited without limit by their employers, but individuals who under certain conditions are able to conduct organised collective actions to promote their own interests. These possibilities have

27. The Provisions of Shanghai municipality on the Administration of real estate agents, articles 6 and 7 .

28. The rental of such certificates fetches more than 2,000 yuan a year. Cf. "Crackdown on Illegal Property Agencies Will Start Next Month," Shanghai Daily, 22 February 2010, http://www.shanghaidaily.com/sp/article/2010/201002/20100222/article_429145. htm.

29. See Michael B. Arthur and Denise M. Rousseau (eds.), The Boundaryless Career: A New Employment Principle for a New Organizational Era, New York, Oxford University Press, 1996.

30. See P.-P. Zalio, "Sociologie économique des entrepreneur," in Philippe Steiner et François Vatin (eds.), Traité de sociologie économique, Paris, Puf, 2009, pp. 573-608; and P.-P. Zalio, "Les entrepreneurs enquêtés par les récits de carrière : De l'étude des mondes patronaux à celle de la grammaire de l'activité entrepreneuriale," Sociétés contemporaines, 2007, vol. 68, no. 4, pp. 59-82. 
to be associated with the industry of real estate broking itself, an activity that is difficult to regulate. ${ }^{(31)}$

\section{Entering the industry}

Networks are useful at the very first step of entering the city and the industry. Many of those interviewed were introduced to Shanghai and to the industry by classmates. Xie had three classmates who came to Shanghai and then advised him to join them. That's how he arrived in the city. He came without any specific ideas and was willing to consider any opportunity. He looked at job advertisements, and that's how he found his first job. Sun had university classmates who worked in the industry and introduced him. Fan entered the industry "by chance." In fact, he had some university classmates who already worked in real estate. When he graduated, the old system of employment had disappeared and he had to rely on himself to find employment. So he followed one of his university friends' advice and came to Shanghai to work in real estate. Yang had many friends who already worked in the industry before entering it herself. Xiao had a classmate already working in the industry and earning 10,000 yuan a month. Only one of our informants came to the city without previous connections on his own initiative:

I came on my own to Shanghai. I had no friends. I had a small backpack, with a few clothes. Leaving the station, I was able to rent a room for a low price near a university in Putuo District. I rented a room. I had come with a small amount of money. (Han)

\section{Networking with colleagues}

For these young employees, professional life and social life are highly interconnected. Since they have very long working hours and hardly any time for themselves, their social life is very much connected with their job. As a result, many acknowledged in the interviews that most of their friends, besides their classmates from their original towns, were working in the same industry.

- Ninety percent of my friends do that job or related jobs. For instance, they work in banks where they're in charge of bank loans. Ten percent are in some other industry, but many of them would like to enter the real estate industry. For instance, I have friends working in banks. And when you are in charge of bank loans, it can lead to working in real estate (...).
- Question: Did you meet them through your job?

- It is not always the case. Several are classmates. Others were introduced through friends. I met some others through my work in real estate. (Yang)

\section{I have a lot of friends. In that industry? More than ten, 20 or even more. Since I graduated, I haven't had time to do anything else. Since I graduated, two thirds of the people I've met are working in that in- dustry. Or they're my clients. The rest are my friends from my youth, former classmates. (Xie) \\ Most of my friends are in the industry, in other com- panies. They sell new programs, they work for devel- opers. They're in different fields, but still in real es- tate. (Han)}

From the narratives collected, it is impossible to tell if these are closed networks limited to people from the same local origins, though the issue was occasionally mentioned through comments on "classmates." More generally, it seems that the social and personal identity of these young white-collars is completely reconstructed around their professional activity.

The importance of the industry as a social resource for friendship is not only related to the organisation of labour and the fact that they do not have much time for leisure. Having friends in the same industry, among colleagues in the same company or in other companies, can also be crucial for gathering information about the market: a new property soon coming on the market, a new client looking for a specific product, a new administrative regulation that will bring prices up or down, a new job opportunity, etc.

Competition between brokers is intense. In Shanghai, it is not rare to have five or more real estate agencies one next to the other on the same street. Within large companies with dozens of branches in the city, there is even internal competition, or competition between employees of a single branch. One of our hypotheses is that personal relationships among brokers are one way to regulate the sharp competition either between companies or between employees within the same firm or the same branch:

Someone who works for us [our company] for a while can easily transfer later to one of our neighbours.

31. A key step was the publication of the Provisional Regulations on the Professional Qualification System of Real Estate Brokerages (Fang dichan jingji renyuan zhiye zige zhidu zhan hang guiding) in December 2001. But norms of operations have yet to be standardised. See Ge Hongling (ed.), Fangdichan jingjiren (Real estate brokers), Beijing, Zhongguo jingji chubanshe, 2003. 
There are four companies [on the same street], and we have friends in each of them. All of us are employees, that's the first point. Another important point, it is something that often happens... The more friends you have, the more successful you are in your job. In real estate, let's suppose that one owner puts his apartment in our shop window and that other brokers don't know about it. If you have friends, they will know. It can be an advantage. It can be a disadvantage. If we're close to making a deal and your neighbours know about it... it is possible that some of them will act maliciously so you can't finalise the deal in the end." (Yang)

Since labour contracts are highly flexible and positions insecure - employees can easily be dismissed and can equally easily quit on their employer - in a context of sharp competition, socialising with colleagues in the same branch, in the same firm, or employed by competitors at the same location, may be one way for employees to build up some control over their job.

Interviews reveal that under certain conditions, skills are actually not individually controlled but are shared by a group of colleagues. Teams can be made up of a limited number of employees from the same branch who may not share the same hierarchical position, and whose cooperation is not necessary formally inscribed in the labour organisation. In the case of Han, at one point in his career, he left company $\mathrm{D}$ to work for company $\mathrm{F}$ with a group of ten other colleagues. In another case, it was a group of five colleagues, led by a manager who was successively recruited by one competitor and then by a second. Here, the career was not made by one individual but by a group of brokers who were well known in the profession - in one segment of the market: either a type of product, a clientele or a specific location, etc. - and sold their abilities to the highest bidder.

\section{Socialising with clients}

Networking is not limited to people of the same age, local origin, industry of employment, or social class; it also involves clients. As mentioned earlier, a key resource is one's pool of clients. Spending time with potential clients and making friends with them is part of the job. Xie talked about his clientele in the following terms:

Maybe today you don't intend to buy property, but you will two or three years from now, or later. It often happens that former clients with whom I made a deal become my friends. We often have lunch or dinner together. My clients? I consider them my friends (...). Making friends is something very natural for me. I don't meet them with any precise intentions (...). Doing this job, you learn a lot. The first thing you learn is to socialise. Some people are naturally calm. Some others are not. With each of them, you need to have the proper word, to behave differently. You need to adjust yourself psychologically. Doing this job, you never stop learning new techniques. (Xie)

What this narrative suggests is that one of the key skills brokers have to master is the ability to deal with clients from all walks of life. It is especially the case for those dealing with high purchasing power clients who belong to a completely different social world - they are highly educated and have often lived overseas, if they are not overseas Chinese or foreigners.

Since properties on the market are highly interchangeable especially in new developments (while products are very specific in pre-1949 residential buildings) - one hypothesis to be confirmed by further research is that personal relationships with clients offset the standardisation of the products. Whereas various properties in a particular location are often more or less the same - new developments consist of hundreds or thousands of mass-produced apartments designed along only a few types - and the broker's job itself always follows the same pattern, the only way for a broker to add personal value to a transaction is to develop a personal relationship with his or her clients.

Through the narratives of these young white-collar migrants working in the real estate industry, a socially disadvantaged job, our aim was to understand in what ways they adjust to the conditions of the modern Chinese metropolis. Moderately skilled, coming from the outside, they cannot aspire to the best jobs offered in administrations, state-controlled companies, or private domestic or international firms, which are stable, better paid, and socially approved. Those jobs are reserved to locals. But the commodification of housing has created a wide range of new professions, notably of services and intermediaries that have been filled in part by outsiders. ${ }^{(32)}$ Those who join the real estate industry at the bottom level of its hierarchy end up working long hours, doing repetitive

32. In fact, further research should pay attention to the chronology, since the institutionalisation of the broker profession may have led to an increasing number of local Shanghainese entering the industry. 
tasks, in a very competitive environment, and under the supervision of co-workers and managers. Nevertheless, while entering an unstable and risky profession, some of these moderately-skilled migrants are able to develop strategies to move up the professional and social scales. Many never realise their golden dream, but some are able to develop entrepreneurial strategies. These strategies are made possible by the structural features of the profession. Employees can accumulate knowledge and gradually build capacities. They can take control of a pool of properties and a pool of clients, and master a network of relationships among colleagues within their company or across various companies. These capacities then enable them to counterbalance the high degree of competition between brokers and provide customer-designed services when they are supposed to be highly standardised. The low barrier of entry into the industry and its low level of legal control - the ease of practicing without being officially registered - also enables individuals to take advantage of the ups and downs of the industry: working independently when the market is at the top of the cycle, going back to salary work when it is at the bottom. These processes allow them to take control of their work and resist exploitation.

We may consider this new labour regime another trick of capitalism that ultimately perpetuates workers exploitation, since there is no reason to consider them less exploited as their own bosses than as employees. We nevertheless suggest taking these narratives seriously, since they reveal the concrete functioning of one specific urban labour market. Biographical interviews disclose to the sociologist information that is not available through labour contracts or corporate organisational charts: that these young white-collar workers are not passive atomised individuals submissive to highly flexible labour markets. Disembedded from traditional social structures such as family or danwei, young white-collar migrants, once in the metropolis, are under certain conditions re-embedded in more labile social structures that enable them to work out individual strategies and collective actions to build, sometimes, successful careers. •

\begin{tabular}{|c|c|}
\hline \multicolumn{2}{|l|}{ Glossary } \\
\hline biandi dou shi huangjin & 遍地都是黄金 \\
\hline danwei & 單位 \\
\hline dazhuan & 打轉 \\
\hline duli jinggjiren & 獨立經紀人 \\
\hline fangdichan jingjiren & 房地產經紀人 \\
\hline fenpei & 分配 \\
\hline gaoji wuye guwen & 高級物業顧問 \\
\hline gaoji yingye zhuren & 高級營業主人 \\
\hline geng fuhe wo de xingqu & 更符合我的興趣 \\
\hline geren de fazhan kongjian & \\
\hline shoudao xianzhi & 個人的發展空間受到限制 \\
\hline haigui & 海澠 \\
\hline Jingjiren guanli banfa & 經紀人管理辦法 \\
\hline jingli & 經理 \\
\hline $\mathrm{ku}$ & 苦 \\
\hline lai wan & 來玩 \\
\hline lao kehu & 老客户 \\
\hline mei you zhimingdu & 沒有知名度 \\
\hline qingsong & 輕鬆 \\
\hline tailei & 太累 \\
\hline waidiren & 外地人 \\
\hline wo yizhi zai xunqiu ziji & \\
\hline yao gan shenme & 我一直在寻求自己要赶什么 \\
\hline wuye guwen & 物業顧問 \\
\hline xiagang & 下崗 \\
\hline xiang jinru shichanghua & \\
\hline de gongsi gongzuo & 想進入市場化的公司工作 \\
\hline xiaolü tai di & 效率太底 \\
\hline zhongjie & 中介 \\
\hline
\end{tabular}

\section{ossary}

danwei

dazhuan

duli jinggjıren

gaoji wuye guwen

yingye zhure

geren de fazhan kongjian udao xianzh

海龜

苦

沒有知名度

軭堭 